\title{
Adrenal Steroids Mediate the Increase of Hippocampal Nerve Growth Factor Biosynthesis Following Bicuculline Convulsions
}

\author{
Feng-yan Sun, Ph.D., Erminio Costa, M.D., and Italo Mocchetti, Ph.D.
}

Northerm blot analysis of nerve growth factor (NGF) messenger ribonucleic acid ( $m R N A$ ), together with a two-site enzyme immunoassay for NGF protein, showed that a convulsive dose of bicuculline $(0.4 \mathrm{mg} / \mathrm{kg}, \mathrm{IV})$ induced a rapid (within 1 hour) three-fold increase in hippocampal NGF $m R N A$. This increase was followed by - significant increase in NGF protein 5 hours later. No changes were detected in the cerebral cortex. The increase of rat hippocampal NGF $m R N A$ and protein content was asociated with an increase in plasma corticosterone content. Both responses were completely prevented by a petreatment with diazepam $(5 \mathrm{mg} / \mathrm{kg}, I P)$, which sugested that adrenal steroids might be a stimulus underlying the rapid increase in NGF biosynthesis following bicuculline convulsions. Therefore, we tested to determine whether a convulsive dose of bicuculline could increase NGF mRNA in adrenalectomized and sham-operated rats. Bicuculline increases hippocampal NGF mRNA in sham-operated rats, but not in adrenalectomized rats despite the presence of convulsions in both experimental groups. Moreover, in adrenalectomized rats, dexamethasone $(0.5 \mathrm{mg} / \mathrm{kg}, \mathrm{SC})$ could partly restore the increase in hippocampal NGF $m R N A$ content induced by bicuculline convulsions; thus, adrenal steroids might have an essential role in the induction of hippocampal NGF biosynthesis elicited by bicuculline convulsions. [Neuropsychopharmacology 8:219-225, 1993]
VY WORDS: Nerve growth factor; Hippocampus; Convulsions; Steroids; Bicuculline; Benzodiazepine

Thephysiologic function of nerve growth factor (NGF) forspecific populations of neurons of the peripheral nervous system (Levi-Montalcini and Angeletti 1968) and the central nervous system (CNS) (Thoenen et al. 1987) is well documented. Nerve growth factor is an essential neurotrophic factor for the differentiation and sur-

From the Fidia-Georgetown Institute for the Neurosciences (F-YS $\mathrm{EC}$ and Department of Anatomy and Biology (IM), Georgetown University Medical School, Washington, DC.

Address reprint requests to: Dr. Erminio Costa, Fidia-Georgetown hetitute for the Neurosciences, Georgetown University School of Medicine, 3900 Reservoir Road, NW, Washington, DC, 20007.

Received March 24, 1992; revised July 10, 1992; accepted July 23, Y92. vival of sympathetic neurons, neuronal crest-derived peripheral sensory neurons, and forebrain cholinergic neurons (Levi-Montalcini and Angeletti 1968; Cohen 1960; Aloe et al. 1981; Angeletti et al. 1971; Thoenen and Barde 1980; Thoenen et al. 1987; Whittemore and Seiger 1987). Nerve growth factor can be expressed in specific populations of CNS neurons (Whittemore and Seiger 1987; Whittemore et al. 1988); however, little is known about mechanisms regulating NGF availability in the adult CNS. The modifications induced by NGF in target neurons might participate in enhancing neuronal plasticity; therefore, by learning the molecular mechanisms regulating NGF biosynthesis, we may be able to activate neuronal plasticity in the CNS via a pharmacologically induced increase of NGF availability.

In the adult rat brain, NGF expression can be increased by different types of seizures (Gall and Isack- 
son 1989; Gall et al. 1991; Isackson et al. 1991; Ernfors et al. 1991; Zafra et al. 1990). Moreover, steroids released from adrenal glands during stress can increase the content of NGF messenger ribonucleic acid (mRNA) and NGF immunoreactivity in specific brain regions (Aloe et al. 1989; Fabrazzo et al. 1991; Mocchetti et al. 1991). Several lines of evidence suggest a direct relationship between seizure activity and blood-steroid levels (Craig 1966; Holmes et al. 1984; Backstrom et al. 1985; Bowers et al. 1991; Lee et al. 1987). However, it is not known whether steroids can activate brain NGF biosynthesis following seizures. In the present study, we tested to determine whether adrenal steroids released following bicuculline-elicited convulsions, modulate the increase of NGF synthesis in the CNS.

\section{MATERIALS AND METHODS}

\section{Treatment of Animals}

Adult male Sprague-Dawley rats weighing between 200 and $260 \mathrm{~g}$ (Zivic Miller, Allison, PA) were used. Adrenalectomized and sham-operated rats were received from Zivic Miller 5 days postsurgery and experiments began 2 days later. After adrenalectomy, rats drank ad libitum saline solution instead of water. All rats were housed five per cage in a temperature-controlled room with a 12-hour light/dark cycle. Rats receiving $0.4 \mathrm{mg} / \mathrm{kg}$ $(10 \mu \mathrm{mol} / \mathrm{kg})$ of intravenous (+)bicuculline (Sigma, St. Louis, MO) exhibited tonic-clonic convulsions within 10 seconds of injection, which lasted from 2 to $5 \mathrm{~min}$ utes. Dexamethasone $(0.5 \mathrm{mg} / \mathrm{kg}, 1.3 \mu \mathrm{mol} / \mathrm{kg}, \mathrm{SC})$ or diazepam $(5 \mathrm{mg} / \mathrm{kg}, 18 \mu \mathrm{mol} / \mathrm{kg}$, IP, Sigma, St. Louis, MO) was given 3 hours or 10 minutes before bicuculline administration, respectively. Control animals received vehicle injection. Rats were decapitated at the indicated times after treatment and the brains were removed immediately. Cerebral cortex and hippocampi were quickly dissected and stored at $-70^{\circ} \mathrm{C}$ for analysis at a later time.

\section{Probe Preparation}

Clone $\mathrm{pBS}_{2} \mathrm{NGF}$ (a gift from Dr. Whittemore, University of Miami, FL) contains an equivalent 770 bp complementary deoxyribonucleic acid (cDNA) encoding rat $\beta$-NGF (Whittemore et al. 1988). The transcript generated by $\mathrm{T}_{3}$ polymerase is the antisense RNA (cRNA) complementary to $\beta$-NGF mRNA. The in vitro transcription assay was carried out as previously described (Melton et al. 1984) to yield ${ }^{32} \mathrm{P}-\mathrm{cRNA}$ at a specific activity of 5 to $6 \times 10^{8} \mathrm{cpm} / \mu \mathrm{g}$ of RNA. Clone p1B15 (a gift from Drs. Milner and Sutcliffe, Scripps Clinic, La Jolla, CA), which contains the cDNA encoding the structural protein cyclophilin (Danielson et al. 1988), was labeled by Nick translation procedure (Sambrook et al. 1989).

\section{Preparation of RNA and Northern Blot Analysis}

The total RNA was prepared from the cerebral cortex or hippocampus as previously described (Chirgwin t al. 1979; Fabrazzo et al. 1991). The total RNA was size fractionated by agarose formaldehyde gel electrophoresis and transferred to nylon membrane by the capilary blot procedure. Blots were prehybridized with $50 \%$ formamide, $4 \times$ SSPE, $0.1 \mathrm{mg} / \mathrm{ml}$ denatured salmon sperm DNA and $5 \times$ Denhardt's solution at $65^{\circ} \mathrm{C}$ for at least 2 hours. Hybridization with ${ }^{32} \mathrm{P}$-labeled NGF probe was carried out overnight at $65^{\circ} \mathrm{C}$ in a prehybritization solution containing $1 \times$ Denhardt's solution. The blots were washed in $0.1 \times$ standard saline citrate, $0.1 \%$ sodium dodecyl sulfate at $68^{\circ} \mathrm{C}$ for 2 hours and exposed to Kodak X-OMAT film with an intensifying screen at $-70^{\circ} \mathrm{C}$. After exposure, the radioactivity was removed by washing the blot at stringency conditions as previously described (Mocchetti et al. 1987). The blots were then rehybridized with a ${ }^{32} \mathrm{P}-\mathrm{p} 1 \mathrm{~B} 15 \mathrm{cDNA}$ (Milner and Sutcliffe 1983; Danielson et al. 1988), washed, and exposed to a new X-ray film. The intensity of the autor diographic hybridization bands was quantified by la ser densitometry.

\section{Calculation of RNA}

The amount of NGF mRNA in the blots was estimated in arbitrary units defined as the ratio between the densitometric peak of the major NGF mRNA band $(1.3 \mathrm{~Kb})$ and that of the cyclophilin (p1B15) mRNA. Cyclophlin was used to correct for recovery variations during extraction, purification and hybridization procedures. The value of each control was set equal to 1 and the other calculated relative to it.

\section{Two-site Enzyme Immunoassay of NGF}

Nerve growth factor content was determined by quartitative two-site enzyme immunoassay as previously de scribed (Fabrazzo et al. 1991). Brain extracts for NGF determination were prepared from the hippocampus or cerebral cortex at different times after treatment with either bicuculline $(0.4 \mathrm{mg} / \mathrm{kg} \mathrm{IV})$ or vehicle. All reagents for the immunoassay were obtained from Boehringe Mannheim (Indianapolis, IN).

\section{Plasma Corticosterone Determination}

Trunk blood was collected from decapitated rats in heparinized glass tubes and centrifuged. The plasm was stored at $-20^{\circ} \mathrm{C}$ for corticosterone determination 
at a later time. The content of corticosterone in the plasma was measured by radioimmunoassay with the RSL ${ }^{125}$ I-corticosterone Kit (ICN, Costa Mesa, CA). The antibody from the kit is specific against corticosterone with less than $0.01 \%$ cross-reactivity to cholesterol, estrone, pregnenolone, and their metabolites. All measurements were within the linear range of the assay as determined by a standard curve.

\section{Data Analysis}

Differences among means were evaluated by analysis d variance. When the drug treatment elicited significant dranges, significance was determined by Dunnett's test for comparing the treatment and control groups or Scheffé's test for multiple comparisons.

\section{RESULTS}

\section{Effect of Bicuculline on Hippocampal NGF mRNA Content}

The dose-response relationship between bicucullineinduced convulsions and the increase in hippocampal NGF mRNA content is reported in Table 1. Bicuculline * doses from 0.05 to $0.2 \mathrm{mg} / \mathrm{kg}$ (IV) failed to induce convulsions or to increase the hippocampal NGF aRNA content. Only at a dose of $0.4 \mathrm{mg} / \mathrm{kg}$ does bicrulline induce tonic-clonic convulsions, which occur 10 seconds after injection and last from 2 to 5 minutes. The hippocampal content of NGF mRNA is increased about three-fold 1 hour after the administration of a convulsive dose $(0.4 \mathrm{mg} / \mathrm{kg}, \mathrm{IV})$ of bicuculline, whereas the cortical NGF mRNA content remains unchanged (Fig. 1). This dose of bicuculline was used to study the time course of NGFmRNA increase following convulsions. As shown in Fig. 2, the hippocampal NGF mRNA con-

Table 1. Dose Response of Bicuculline-Induced Convulsions and Hippocampal NGF mRNA Expression

\begin{tabular}{lcc}
\hline Treatment & Convulsions & $\begin{array}{c}\text { NGF mRNA } \\
\text { (Arbitrary Units) }\end{array}$ \\
\hline $\begin{array}{l}\text { Control } \\
\text { Bicuculline }\end{array}$ & No & 1 \\
$0.05 \mathrm{mg} / \mathrm{kg}$ & No & $1.1 \pm 0.12$ \\
$0.1 \mathrm{mg} / \mathrm{kg}$ & No & $1.2 \pm 0.11$ \\
$0.2 \mathrm{mg} / \mathrm{kg}$ & No & $1.3 \pm 0.0070$ \\
$0.4 \mathrm{mg} / \mathrm{kg}$ & Yes & $3.2 \pm 0.25^{\star \star}$ \\
\hline
\end{tabular}

Animals were injected intravenously with the indicated doses of Luculline or vehicle and decapitated 1 hour after the injection. Nerve growth factor mRNA was estimated by Northern blot analyis. Control value was set equal to 1 and the other value calculated reltive to it. Data are the mean \pm SEM of three independent experiments. " $p<0.01$ versus control group.
A
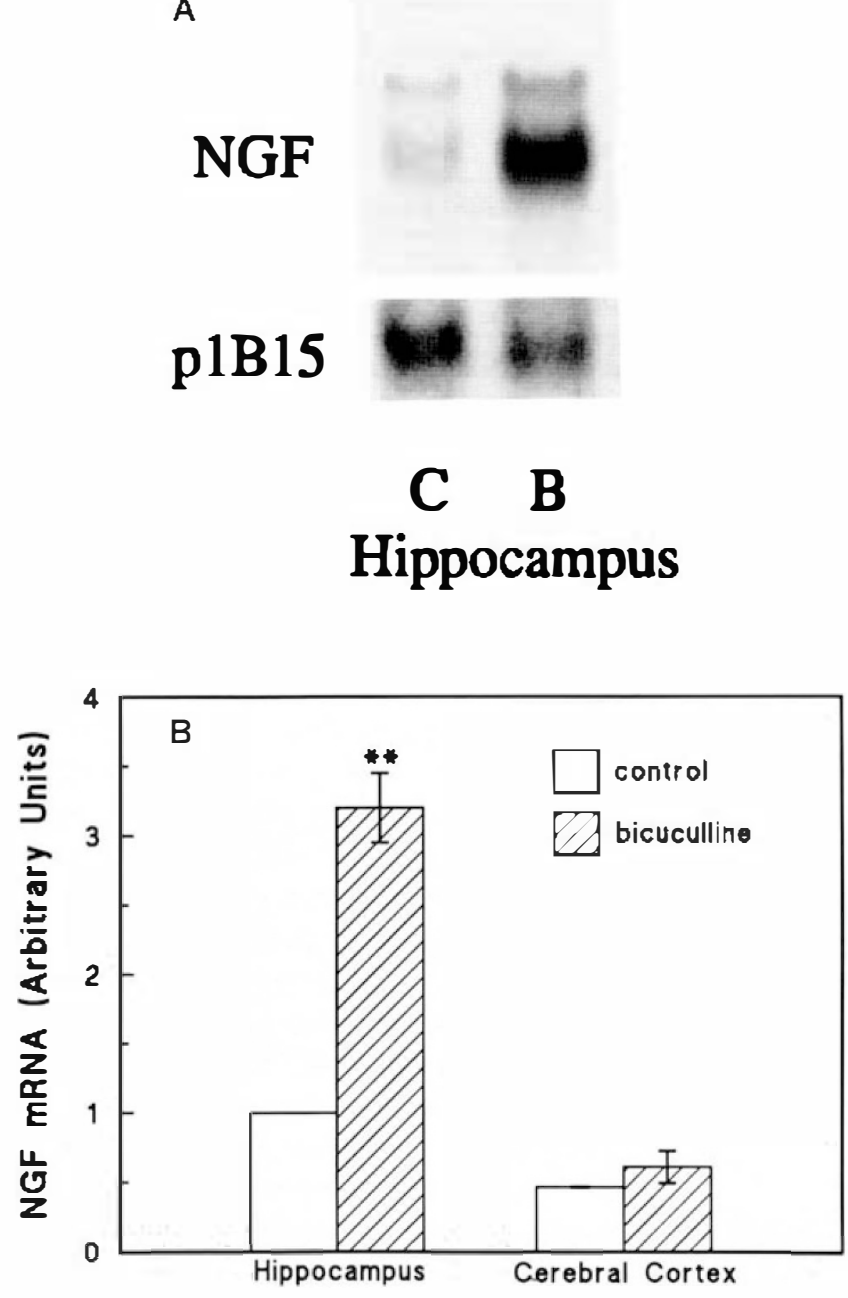

Figure 1. Bicuculline increases NGF mRNA in rat hippocampus. (A) Northern blot analysis of RNA from hippocampus of adult rats 1 hour after bicuculline $(B=0.4 \mathrm{mg} / \mathrm{kg}$, IV) or vehicle $(C)$ treatment. Blot was hybridized with NGF cRNA probe (NGF), washed, exposed to x-ray film for 24 hours, and washed again. Blot was rehybridized with cyclophilin cDNA (p1B15), washed, and exposed for 6 hours. (B) Densitometric analysis of NGF mRNA content in hippocampus and cerebral cortex. Nerve growth factor mRNA content is expressed in arbitrary units. Data are the mean \pm SEM of three independent experiments. ${ }^{* *} p<0.01$ versus control group.

tent is already significantly increased above control levels 30 minutes after bicuculline injection, reaches peak values at 1 hour, and returns to control levels within 9 hours(Fig. 2A). The hippocampal content of NGF protein increases at 6 hours and returns to the basal level within 24 hours postadministration of bicuculline (Fig. 2B). However, in the cerebral cortex, neither NGF mRNA nor NGF protein content changes during this time period (Fig. 2A and B). 

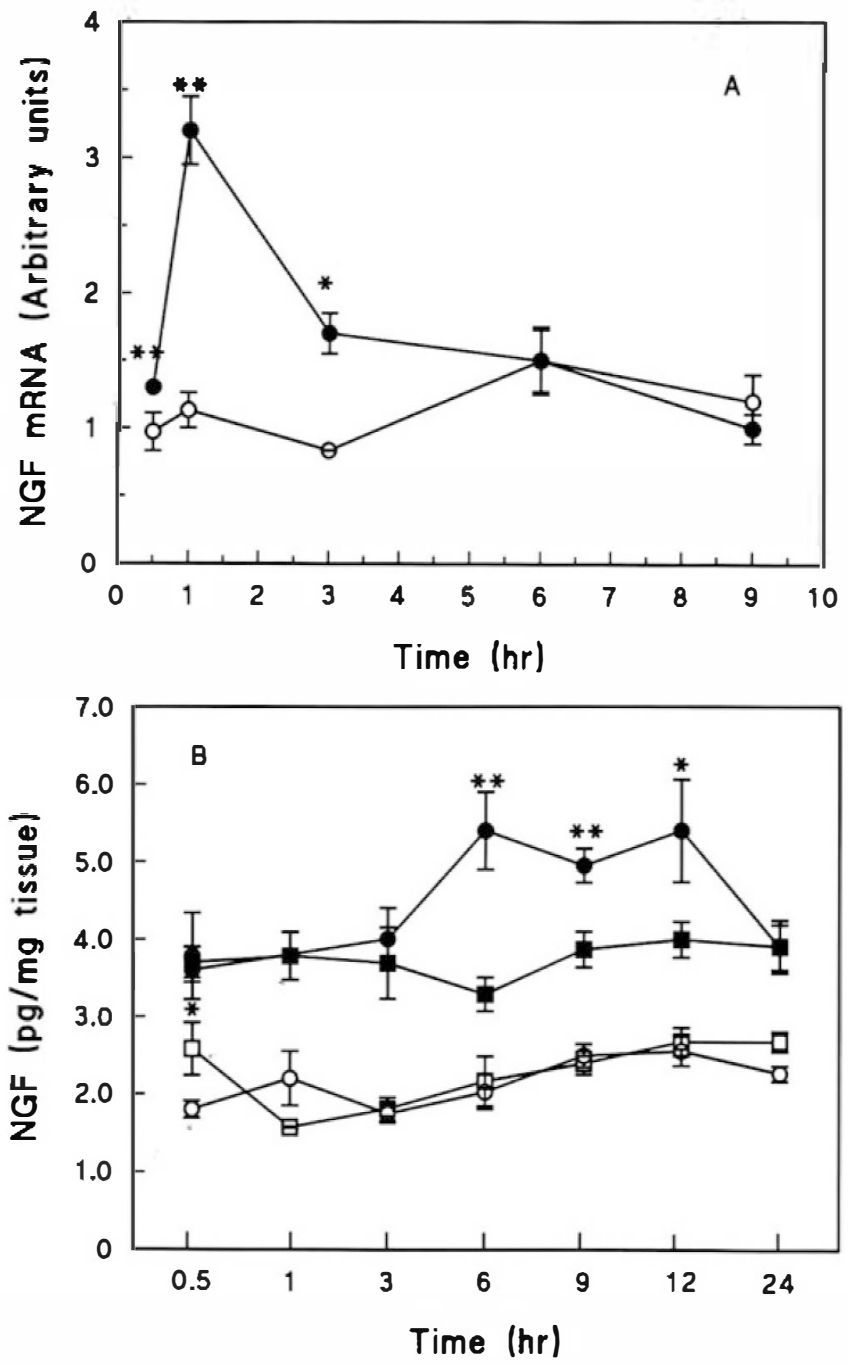

Figure 2. Time course of bicuculline-elicited increase of NGF mRNA A and NGF Protein B contents in the cerebral cortex and hippocampus. Rats were decapitated at the indicated times after a single injection of bicuculline $(0.4 \mathrm{mg} / \mathrm{kg}, \mathrm{IV})$ or vehicle. Filled circles indicate hippocampus of bicucullinetreated rats; filled squares indicate hippocampus of vehicletreated rats; open circles indicate cerebral cortex of bicucullinetreated rats; and open squares indicate cerebral cortex of vehicle-treated rats. (A) The amount of NGF mRNA was estimated by Northern blot hybridization analysis. Arbitrary units were calculated as described in the Materials and Methods section. The value for control rats (each time point) was set equal to 1 and other values calculated relative to it. Data are the mean \pm SEM of three independent experiments. (B) The content of NGF protein was measured by a two-site enzyme immunoassay. The mean $\pm \operatorname{SEM}(n=6)$ are shown. " $p<0.05 ; "$; $p<0.01$ versus control group.

\section{Diazepam Antagonism of Bicuculline-Mediated Increase of Hippocampal NGF mRNA Content}

Several lines of investigation have shown that benzodiazepine recognition sites are located in the gamma aminobutyric acid-A $\left(\mathrm{GABA}_{\mathrm{A}}\right)$ receptor structure and, when bound by various drugs, they can modulatechar nel gating by GABA in a positive or negative modul tion. Diazepam, a positive allosteric modulator $\alpha$ GABA action in several $\mathrm{GABA}_{\mathrm{A}}$ receptor subtype has been tested to evaluate the role of convulsions in eliciting the increase of hippocampal NGF mRNAcortent. Diazepam at a dose of $5 \mathrm{mg} / \mathrm{kg}$ (IP) prevents bicuculline-induced convulsions, the increase in plasw corticosterone levels, and also inhibits the inductiond hippocampal NGF mRNA (Table 2). Diazepam cour pletely prevents both of these biochemical changr mediated by bicuculline convulsions without any effed per se on the basal levels of the abovementioned param eters (Table 2).

\section{Effects of Adrenal Steroids on Bicuculline-Mediated Induction of Hippocampal NGF mRNA}

Plasma corticosterone levels increase following birr culline-induced convulsions (Table 2), which suggest that convulsions induce the release of adrenal steroids. To ascertain whether the increase of the hippocamps content of NGF mRNA elicited by bicuculline is related to the increase of blood-borne adrenal steroids, we perimented with bilaterally adrenalectomized and sham-operated rats. Bicuculline increases hippocampal NGF mRNA content in sham-operated rats, but not in adrenalectomized rats (Table 3 ), despite the presene of convulsions in both groups. These results suppor the view that the increase of blood-borne corticosternid plays a role in bicuculline's induction of hippocampal NGF mRNA. Dexamethasone, a synthetic glucocorticoid, was given to adrenalectomized and sham operated rats 3 hours before bicuculline administration. Figure 3 shows that dexamethasone $(0.5 \mathrm{mg} / \mathrm{kg}, \mathrm{SO}$ alone elicits an increase of approximately 1.5 -fold $\alpha$ NGF mRNA content in the cerebral cortex, but not in

Table 2. Antagonism by Diazepam of BicucullineInduced Convulsions and Increase of Hippocampal NGF mRNA and Plasma Corticosterone Contents

\begin{tabular}{|c|c|c|c|}
\hline Treatment & $\begin{array}{c}\text { Convul- } \\
\text { sions }\end{array}$ & $\begin{array}{c}\text { NGF mRNA } \\
\text { (Arbitrary Units) }\end{array}$ & $\begin{array}{l}\text { Cortion } \\
\text { steron } \\
\text { (ng/n } \\
\text { Plasmal }\end{array}$ \\
\hline Control & No & 1 & $33 \pm 8.7$ \\
\hline Bicuculline & Yes & $3.2 \pm 0.25$ & $63 \pm 7.7$ \\
\hline Diazepam & No & $0.73 \pm 0.12$ & $30 \pm 6.3$ \\
\hline \multicolumn{4}{|l|}{ Diazepam + } \\
\hline Bicuculline & No & $0.67 \pm 0.009 * *$ & $35 \pm 3.8$ \\
\hline
\end{tabular}

Diazepam $(5 \mathrm{mg} / \mathrm{kg}$, IP) was injected 10 minutes before the 4 ministration of bicuculline $(0.4 \mathrm{mg} / \mathrm{kg}$, IV). Rats were decapitind 1 hour after bicuculline injection. Nerve growth factor mRNA wo estimated by Northern blot analysis $(n=3)$. Plasma corticostere was determined by radioimmunoassay $(n=7)$. Data are the mean : SEM. ${ }^{\star} p<0.05$ or ${ }^{\star \star} p<0.01$ versus bicuculline. 
Table 3. Bicuculline Fails to Increase NGF mRNA in Adrenalectomized Rats

\begin{tabular}{|c|c|c|c|c|c|c|}
\hline \multirow[b]{3}{*}{ Cooups } & \multicolumn{4}{|c|}{ NGF mRNA (Arbitrary Units) } & \multirow{2}{*}{\multicolumn{2}{|c|}{ Convulsions }} \\
\hline & \multicolumn{2}{|c|}{ Hippocampus } & \multicolumn{2}{|c|}{ Cerebral Cortex } & & \\
\hline & Sham-Operated & Adrenalectomized & Sham-Operated & Adrenalectomized & Sham-Operated & Adrenalectomized \\
\hline $\begin{array}{l}\text { Control } \\
\text { livuculline }\end{array}$ & $\begin{array}{c}1 \\
2.5 \pm 0.13^{\star \star}\end{array}$ & $\begin{array}{l}1.2 \pm 0.14 \\
1.5 \pm 0.21\end{array}$ & $\begin{array}{c}1 \\
0.98 \pm 2.26\end{array}$ & $\begin{array}{c}1.0 \pm 1.4 \\
0.80 \pm 0.008\end{array}$ & $\begin{array}{l}\text { No } \\
\text { Yes }\end{array}$ & $\begin{array}{l}\text { No } \\
\text { Yes }\end{array}$ \\
\hline
\end{tabular}

Expeniments on adrenalectomized and sham-operated rats began 1 week after surgery. Rats were decapitated 1 hour after bicuculline dministration. Nerve growth factor mRNA was estimated by Northern blot analysis. Data represent the mean \pm SEM of three experients. " $p<0.01$ versus control group.

the hippocampus of sham-operated rats. Coadministration of bicuculline and dexamethasone can further diot an increase in cortical NGF mRNA content of about 3 and 1.8-fold in sham-operated and adrenalectomized rats, respectively. Bicuculline or dexamethasone given done, fails to change the basal levels of hippocampal NGF mRNA in adrenalectomized rats. However, in these animals, bicuculline coadministrated with dexamethasone significantly increases the hippocampal NGF oRNA content by about 1.7 -fold. These data sugcost that in adrenalectomized rats dexamethasone can purtially restore the ability of bicuculline to increase the hippocampal NGF mRNA expression.

\section{DISCUSSION}

Drugsthat decrease brain GABAergic tone usually elicit sinures (Loscher 1982; Kendall et al. 1981; Loscher and frey 1979). In the present study, bicuculline, an isosteric $\mathrm{GABA}$ antagonist at $\mathrm{GABA}_{\mathrm{A}}$ receptors, was used in normal, adrenalectomized, and sham-operated rats to induce tonic-clonic convulsions. We investigated whether convulsions induce the expression of NGF in the adult CNS and we characterized the mechanisms whereby convulsions increase NGF. Bicuculline, at the convulsive dose, increased plasma corticosterone, hippocampal NGF mRNA, and protein contents. Diazepam, a positive allosteric modulator of the $\mathrm{GABA}_{\mathrm{A}}$ receptor (Costa and Guidotti 1979), not only prevented the bicuculline-induced convulsions and the increase in plasma corticosterone levels, but also inhibited the induction of hippocampal NGF mRNA. These results demonstrate that behavioral and biochemical changes induced by bicuculline are antagonized by enhancing GABAergic transmission and suggest that the cascade of events leading to the accumulation of NGF is initiated by $\mathrm{GABA}_{\mathrm{A}}$ receptor blockade.

Nerve growth factor protein accumulates following the increase in NGF mRNA. These data suggest that, whether bicuculline increases gene expression or mRNA stabilization, it enhances NGF production.
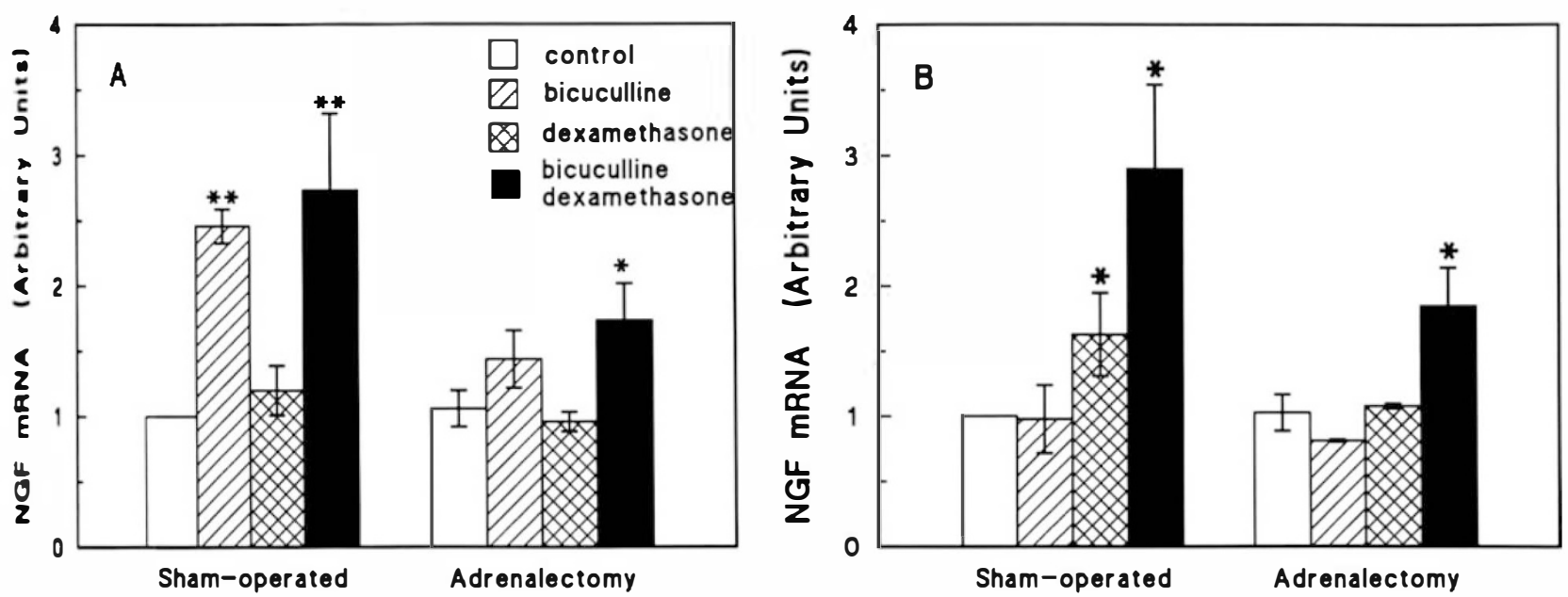

Figu 3. Dexamethasone partially restores bicuculline-induced increase of brain NGF mRNA in adrenalectomized rats. Cupcriments on adrenalectomized and sham-operated rats began 1 week after operation. Dexamethasone $(0.5 \mathrm{mg} / \mathrm{kg}, \mathrm{SC})$ a vehicle was administrated to the animals 3 hours before administration of bicuculline or vehicle. Rats were decapitated thour after bicuculline or vehicle treatment. Nerve growth factor mRNA contents in hippocampus $\mathbf{A}$ and cerebral cortex B were estimated by Northern blot analysis. Data represent the mean \pm SEM of four independent experiments. " $p<0.05$ and " $p<0.01$ versus each control group. 
Thus, it might be concluded that bicuculline increases hippocampal NGF biosynthesis rather than decreasing NGF utilization or degradation. However, the selective action of bicuculline on hippocampal NGF mRNA content contradicts a direct action of bicuculline and favors an indirect action. A direct relationship between seizure activities and adrenal steroids has been demonstrated (Craig 1966; Holmes et al. 1984; Backstrom et al. 1985; Bowers et al. 1991; Lee et al. 1987). Bicuculline given at the convulsive dose induces the release of adrenal steroids. Thus, we considered the possibility that the GABAergic receptor antagonist may act on brain NGF biosynthesis via an increase in plasma corticosterone levels. Previous data have shown that glucocorticoids increase NGF in the CNS (Fabrazzo et al. 1991). To evaluate whether corticosteroid released from the adrenal gland following bicuculline-induced convulsions participate in the enhancement of NGF mRNA, we resorted to the strategy of testing to determine whether bicuculline increases brain NGF mRNA in adrenalectomized rats. Interestingly, we observed that adrenalectomy could abolish the bicuculline-induced increase in hippocampal NGF mRNA content, despite the presence of convulsions. Actually, convulsions appeared more severe and longer lasting in adrenalectomized rats, thus confirming the report of Bowers et al. (1991). In adrenalectomized rats, dexamethasone can partially restore the bicuculline enhancement of hippocampal NGF mRNA content. These results demonstrate that blood-borne steroids play a major role in modulating the increase in NGF mRNA content elicited by bicuculline convulsions. However, dexamethasone alone failed to change the content of NGF mRNA, suggesting that in the hippocampus, glucocorticoids are not the main adrenal steroids involved in the bicuculline-mediated induction of NGF mRNA. Indeed, our experiments failed to elucidate how adrenal steroids regulate hippocampal NGF gene expression and which adrenal steroids (mineralcorticoids?), specifically participate in this regulation.

In the cerebral cortex, bicuculline failed to change NGF mRNA and protein levels. However, in this brain area, but not in the hippocampus, dexamethasone increases NGF availability in developing (Fabrazzo et al. 1991) and adult rats. This anatomic specificity of NGF induction suggests that NGF expression is regulated in different brain areas by different neural circuitry. Our studies failed to demonstrate whether bicucullinemediated NGF expression occurs in neurons or in astrocytes. Nevertheless, we cannot rule out the possibility that in the cerebral cortex, cell synthesizing NGF might express both GABAA and steroid receptors. Indeed, when bicuculline and dexamethasone were concomitantly administered, dexamethasone elicited a stronger effect on cortical NGF expression, suggesting that induction of glucocorticoid-mediated NGF expres- sion is potentiated when the GABAergic transmissin is blocked.

Bicuculline-induced convulsions elicit a rapid in crease in NGF mRNA and protein in the hippocampus, similar to the accumulation of NGF mRNA previoust observed (Gall et al. 1989, 1991; Isackson et al. 199\%; Ernfors et al. 1991). However, unlike the other seizur models, the intravenous injection of bicuculline elids convulsions only for a relatively short time, and NGF mRNA content returns to the basal levels within ? hours. These data suggest that continuous seizur most likely are responsible for prolonged inductiond NGF mRNA. Moreover, the induction of NGF follow. ing convulsions might represent an adaptive event thr is activated in selective brain circuitry. Hence, therapid and transient increase in NGF availability may be im portant for protecting and maintaining the integrityd the brain circuitry via which seizures propagate.

In summary, in adult rat CNS, bicuculline-induced convulsions elicit hippocampal NGF biosynthesis in manner inhibited by diazepam or adrenalectomy. h adrenalectomized rats, dexamethasone can partly is store the bicuculline-induced increase in hippocampt NGF mRNA. These data indicate that blood-borne adre nal steroids may play a role in the increase of hippo campal NGF content following bicuculline convulsions We cannot conclude whether adrenocorticotropichor. mone participates in this regulation because such a notion requires further experiments with hypophyse. tomized rats.

\section{ACKNOWLEDGMENTS}

The authors wish to thank Drs. S. Whittemore and R. Mitre for the precious gift of plasmids. This work was suppord in part by Health and Human Services Grant NS2966.

\section{REFERENCES}

Aloe L (1989): Adrenalectomy decreases nerve growth facte in young and adult rat hippocampus. Proc Natl Acad 50 USA 86:5636-5640

Aloe L, Cozzari C, Calissano P, Levi-Montalcini R(1981):So matic and behavioral postnatal effects of fetal injection of nerve growth factor antibodies in the rat. Natue 291:413-415

Angeletti PU, Levi-Montalcini R, Caramia F (1971): Analy: of the effects of the antiserum to the nerve growth fat in adult mice. Brain Res 27:343-355

Backstrom T, Bixo M, Hammarback S (1985): Ovarian sterid hormones: Effect on mood, behavior and brain excitaty ity. Acta Abstr Gynecol Scand Suppl 130:19-24

Bowers BJ, Bosy TZ, Wehner JM (1991): Adrenalectomg : creases bicuculline-induced seizure sensitivity in lon sleep and short-sleep mice. Pharmacol Biochem Betr 38:593-600 
Chirgwin JM, Przybyla AE, MacDonald RJ, Rutter WJ (1979): Isolation of biologically active ribonucleic acid from source enriched in ribonuclease. Biochemistry 18:5294-5299

Cohen S(1960): Purification of a nerve-growth promoting protein from the mouse salivary gland and its neurocytotoxic antiserum. Proc Natl Acad Sci USA 46:302-311

Costa E, Guidotti A (1979): Molecular mechanisms in the receptor action of benzodiazepine. Annu Rev Pharmacol Toxicol 19:531-545

Craig CR (1966): Anticonvulsant activity of steroids: Separability of anticonvulsant from hormonal effects. J Pharmacol Exp Ther 153:337-343

Danielson PE, Forss-Petter S, Brown MA, Calavetta L, Douglass J, Milner RJ, Sutcliffe JG (1988): p1B15: a cDNA clone of the rat mRNA encoding cyclophilin. DNA 4:261-269

Enfors P, Bengzon J, Kokaia Z, Persson H, Lindvall O (1991): Increased levels of messenger RNAs for neurotrophic factors in the brain during kindling epileptogenesis. Neuron 7:165-176

Fabrazzo M, Costa E, Mocchetti I (1991): Stimulation of nerve growth factor biosynthesis in developing rat brain by reserpine: steroids as potential mediators. Mol Pharmacol 39:44-149

Gall C, Isackson PJ (1989): Limbic seizures increase neuronal production of messenger RNA for nerve growth factor in adult rat forebrain. Science 245:758-761

Gall C, Murrary K, Isackson PJ (1991): Kainic acid-induced seizures stimulate increased expression of nerve growth factor mRNA in rat hippocampus. Mol Brain Res 9:113123

Holmes GL, Weber DA, Kloczko N, Zimmerman AW (1984): Relationship of endocrine function to inhibition of kindling. Dev Brain Res 16:55-59

lexkson PJ, Huntsman MM, Murrary KD, Gall C (1991): BDNF mRNA expression is increased in adult rat forebrain after limbic seizures: temporal patterns of induction distinct from NGF. Neuron 6:937-948

Kendall DA, Fox DA, Enna SJ (1981): Effect of gamma-vinyl GABA on bicuculline-induced seizures. Neuropharmacology 20:351-355

Lee PHK, Zhao D, Mitchell CL, Hong J-S (1987): Effects of corticosterone on shaking and sezure behavior induced by deep prepyriform cortex kindling. Neurosci Lett 82:337-342

Levi-Montalcini R, Angeletti PU (1968): Nerve growth factor. Physiol Rev 48:534-569

Loscher W (1982): Comparative assay of anticonvulsant and toxic potencies of sixteen GABAmimetic drugs. Neuropharmacology 21:803-810

Loscher W, Frey HH (1979): Effect of convulsant and anticonvulsant agent on level and metabolism of gammaaminobutyric acid in mouse brain. Naunyn Schmiedebergs Arch Pharmacol 296:263-269

Melton DA, Krieg PA, Rebagliati MR, Maniatis T, Zinn K, Green MR (1984): Efficient in vitro synthesis of biologically active RNA and RNA hybridization probes from plasmids containing a bacteriophage $\mathrm{SP}_{6}$ promoter. Nucleotide Acids Res 12:7035-7056

Milner RJ, Sutcliffe JG (1983): Gene expression in rat brain. Nucleic Acids Res 12:5497-5520

Mocchetti I, Naranjo JR, Costa E (1987): Regulation of striatal enkephalin turnover in rats receiving antagonists of specific dopamine receptor subtypes. J Pharmacol Exp Ther 241:1120-1124

Mocchetti I, Sun FY, Fabrazzo M, Costa E(1991): Steroid regulation of nerve growth factor biosynthesis in the CNS. In CostaE, Paul SM(eds), Neurosteroids and Brain Function. Fidia Research Foundation Symposium Series. Vol. 8, New York, Thieme Medical, pp 41-46

Sambrook J, Fritsch EF, Maniatis T (1989): Molecular Cloning: A Laboratory Manual. Cold Spring Harbor Laboratory, Cold Spring Harbor, NY

Thoenen H, Barde YA (1980): The physiology of nerve growth factor. Physiol Rev 60:1284-1335

Thonen H, Bandtlow C, Heumann R (1987): Physiological function of nerve growth factor in the central nervous system: comparison with the periphery. Rev Physiol Biochem Pharmacol 109:145-178

Whittemore SR, Seiger A (1987): The expression, localization and functional significance of beta-nerve growth factor in the central nervous system. Brain Res 434:439-464

Whittemore SR, Larkfors L, Ebendal T, Holets VR, Ericsson A, Persson H (1987): Increased beta-nerve growth factor messenger RNA and protein levels in neonatal rat hippocampus following specific cholinergic lesions. J Neurosci 7:244-251

Whittemore SR, Friedman PL, Larhammar D, Persson H, Gonzalez-Carvajal M, Holets VR (1988): Rat beta-nerve growth factor sequence and site of synthesis in the adult hippocampus. J Neurosci Res 20:403-410

Zafra F, Hengerer B, Leibrock J, Thoenen H (1990): Activity dependent regulation of BDNF and NGF mRNAs in the rat hippocampus is mediated by non-NMDA glutamate receptors. EMBO J 9:3545-3550 